\title{
Simulation of herbage production and herbage intake during a rotational grazing period: An evaluation of Linehan's formula
}

\section{E. A. Lantinga}

Department of Field Crops and Grassland Science, Agricultural University, Haarweg 333, $6709 \mathrm{RZ}$ Wageningen, Netherlands

Received 4 June 1985; accepted 20 August 1985

Key-words: rotational grazing, herbage production, herbage intake, $\mathrm{CO}_{2}$ assimilation, simulation model

\section{Summary}

The herbage intake under rotational grazing is often estimated with Linehan's formula (Linehan et al., Journal of the British Grassland Society, 1947, 2: 145-168), which takes into account the herbage production during grazing. In the present study this formula was evaluated by means of dynamic simulation, with measured assimilation-light response curves as the main input. There was a close agreement between the intake figures found using the simulation and Linehan's formula for a common rotational grazing system, i.e. a mean sward height of about $18 \mathrm{~cm}$ at the start of a 3-day grazing period and an average daily herbage allowance between 20 and $25 \mathrm{~kg} \mathrm{DM}_{\text {cow }}^{-1} \mathrm{~d}^{-1}$. This result was obtained when herbage mass was measured above a $4-\mathrm{cm}$ stubble. In other practical situations the agreement was less good. This was mainly because Linehan's formula assumes exponential growth of the sward at all stages of growth. Since this is not correct for a sward in the absence of grazing, a new comprehensive formula is developed from the assumption that at the start of grazing the sward is in the linear growth phase.

Comparisons with the simulation output show that this new formula for estimating herbage intake is valid for all situations of rotational grazing.

\section{Introduction}

In the Netherlands, herbage intake by grazing cattle in a rotational grazing system is generally estimated by the sward-cutting technique, i.e. estimating the amount of herbage before and after a grazing period (Meijs, 1981). If the grazing period is longer than one day, as is common practice in the Netherlands, it is desirable to take into account the herbage production during the grazing period. To estimate the magnitude of this herbage production, Linehan et al. (1947) developed a formu- 


\section{E. A. LANTINGA}

la which was validated by means of a large set of estimates of herbage consumption by livestock. Although this formula is widely used, only one article has described a validation test (Iwasaki, 1972), in which grazing was simulated by hand-plucking.

In the present paper the problem of estimating herbage intake during rotational grazing is reconsidered by simulating the herbage production during grazing. Since assimilation is one of the main controlling factors, it is calculated not from an assumed leaf assimilation curve, leaf distribution and leaf area index, but from measured assimilation-light response curves of the sward in the presence and absence of grazing. Linehan's formula is discussed, then the simulation program is presented and discussed. The herbage intake calculated with Linehan's formula is compared with that obtained from the simulation program for different sward growth stages. The influence of radiation level is also studied. Although it appears that under the most common situation of rotational grazing the differences are slight, the agreement is less good in some other situations that occur in practice. A new comprehensive formula is therefore developed and tested; this can be seen as an improved version of Linehan's equation.

\section{Linehan's formula}

Linehan et al. (1947) assumed that at every moment of a rotational grazing period both the rate of consumption of herbage and the rate of herbage production are proportional to the quantity of uneaten herbage at that moment. Thus, they arrived at the following equation for the consumption of herbage:

$$
C=\left(Y_{\mathrm{s}}-Y_{\mathrm{e}}\right) \frac{\ln \left(Y_{\mathrm{u}} / Y_{\mathrm{e}}\right)}{\ln \left(Y_{\mathrm{s}} / Y_{\mathrm{e}}\right)}
$$

in which

$C$ is herbage consumed ( $\left.\mathrm{kg} \mathrm{DM} \mathrm{ha}{ }^{-1}\right)$;

$Y_{\mathrm{s}}$ is herbage mass at start of the grazing period ( $\left.\mathrm{kg} \mathrm{DM} \mathrm{ha}^{-1}\right)$;

$Y_{\mathrm{e}}$ is herbage mass at the end of the grazing period $\left(\mathrm{kg} \mathrm{DM} \mathrm{ha}^{-1}\right)$;

$Y_{\mathrm{u}}$ is herbage mass at the end of the grazing period in an ungrazed area $(\mathrm{kg} \mathrm{DM}$ ha $^{-1}$ ).

Herbage mass refers to the sward layer above a cutting height of approximately 4 $\mathrm{cm}$ (Meijs, 1981). The herbage mass $Y_{\mathrm{u}}$ can be measured in a fenced part of the area to be grazed. The difference between $Y_{\mathrm{u}}$ and $Y_{\mathrm{s}}$ is sometimes termed the 'undisturbed accumulation' (Meijs, 1981).

The herbage production in the grazed paddock can be expressed as a fraction of this 'undisturbed accumulation'. In the case of Linehan's formula this is:

$$
f_{\mathrm{L}}=\frac{\left(Y_{\mathrm{s}}-Y_{\mathrm{e}}\right)}{\left(Y_{\mathrm{u}}-Y_{\mathrm{s}}\right)}\left\{\frac{\ln \left(Y_{\mathrm{u}} / Y_{\mathrm{e}}\right)}{\ln \left(Y_{\mathrm{s}} / Y_{\mathrm{e}}\right)}-1\right\}
$$

Accordingly: 


$$
C=\left(Y_{\mathrm{s}}-Y_{\mathrm{e}}\right)+f_{\mathrm{L}}\left(Y_{\mathrm{u}}-Y_{\mathrm{s}}\right)
$$

where $f_{\mathrm{L}}$ is Linehan's accumulation factor.

In fact, Linehan's formula is based on four simplifying assumptions about the rate of herbage production and the rate of herbage intake.

- Growth of the ungrazed sward at all stages of growth is exponential. It is now known that this assumption is not correct. Already in the 1950's it had been found that during regrowth the rate of herbage production increases more or less exponentially until complete light interception is approached, and that thereafter this rate is almost constant (Brougham, 1956).

- The rate of herbage production during grazing is proportional to the quantity of uneaten herbage above cutting height. Although for the greater part of the grazing period there is a nearly closed canopy, this is more or less correct because the leaves with the greatest assimilatory capacity are grazed first.

- There is no net contribution of the stubble to the production capacity since only the herbage yield above cutting height is taken into account. In Linehan's experiments the cutting height was between 3 and $4 \mathrm{~cm}$. In reality the assimilatory capacity of the stubble below this cutting height can be considerable, especially in spring, and its carbon balance may be positive.

- There is a negative exponential intake pattern over the grazing period. This assumption seems reasonable, except at extreme high levels of herbage allowance. These four assumptions are further evaluated in this paper.

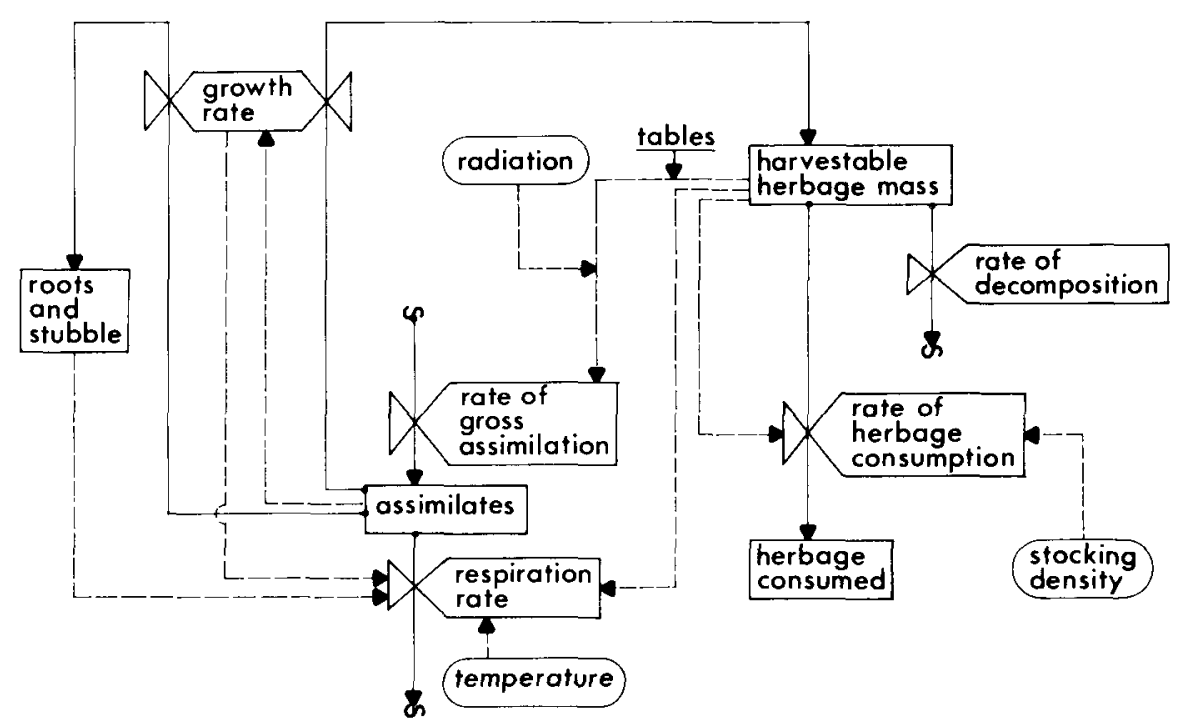

Fig. 1. Relational diagram of the simulation model for the production and consumption of herbage during grazing. Rectangles represent state variables, valves represent rates and ellipses are driving variables. 


\section{E. A. LANTINGA}

\section{The model}

In Fig. 1 is shown a relational diagram of the simulation model for the production and consumption of herbage during a rotational grazing period. It is a dynamic, dry matter-budget model with the state variables 'harvestable herbage mass' and 'herbage consumed' being expressed in units of dry matter per unit ground area $(\mathrm{kg} \mathrm{DM}$ $\mathrm{ha}^{-1}$ ). The model is written in the language CSMP, and the rectilinear method of integration is used. The time interval for the calculations is set at 1 hour, which is short enough to cover the diurnal pattern of temperature and radiant flux density in a satisfactory way.

The average daily temperature was set at $15^{\circ} \mathrm{C}$ with a diurnal amplitude of $10^{\circ} \mathrm{C}$. Calculations were carried out for eight radiation levels (equidistant steps between and including $20 \%$ and $90 \%$ of maximum radiation). The daily pattern of maximum radiant flux density is calculated by means of the procedure described by de Wit et al. (1978) and assumed to be the same for all radiation levels.

\section{Grazing periods and gross assimilation}

The rate of gross assimilation at any moment of a grazing period is calculated using sets of assimilation-light response curves, which were measured at varying amounts of herbage in rotationally grazed paddocks fertilized with $500 \mathrm{~kg} \mathrm{~N} \mathrm{ha}^{-1} \mathrm{yr}^{-1}$. These sets are used in such a way that in the simulation program the herbage mass controls the assimilatory capacity of the sward. The experimental plots, grazing management, herbage and assimilation measurements are described in another paper (Lantinga, 1985). From this experiment the results of the first and fifth grazing periods were taken (spring and summer swards respectively, see Table 1). During both periods the daily global radiation total was about $2750 \mathrm{~J} \mathrm{~cm}^{-2} \mathrm{~d}^{-1}$ for a standard clear sky (Goudriaan \& van Laar, 1978).

In both swards the mean sward height at the onset of grazing was around $18 \mathrm{~cm}$ (Table 1). This is often assumed to be the optimum height for rotational grazing. The corresponding yields are high compared with values reported elsewhere for that sward height. For instance, at a sward height of $18 \mathrm{~cm}$, Meijs (1981) found on average $2000 \mathrm{~kg} \mathrm{DM} \mathrm{ha}^{-1}$ above a $4-\mathrm{cm}$ stubble, irrespective of season. These differences in herbage mass density, i.e. $\mathrm{kg}$ DM per $\mathrm{cm}$ herbage, must be attributed to tiller density. In the spring sward the tiller density was extremely high (about 20000 tillers $\mathrm{m}^{-2}$ ). This resulted in the very high herbage mass density. In the summer sward the tiller density had decreased to about 10000 tillers $\mathrm{m}^{-2}$. This is a more common density in rotationally grazed paddocks.

Table 1. Description of the swards at the start of grazing.

\begin{tabular}{|c|c|c|c|c|}
\hline \multicolumn{2}{|c|}{ Grazing period } & $\begin{array}{l}\text { Sward height } \\
(\mathrm{cm})\end{array}$ & LAI & $\begin{array}{l}\text { Herbage mass above a } 4-\mathrm{cm} \\
\text { stubble }\left(\mathrm{kg} \mathrm{DM} \mathrm{ha}^{-1}\right)\end{array}$ \\
\hline April/May & (spring sward) & 17.1 & 5.0 & 3105 \\
\hline August & (summer sward) & 19.1 & 4.5 & 2490 \\
\hline
\end{tabular}




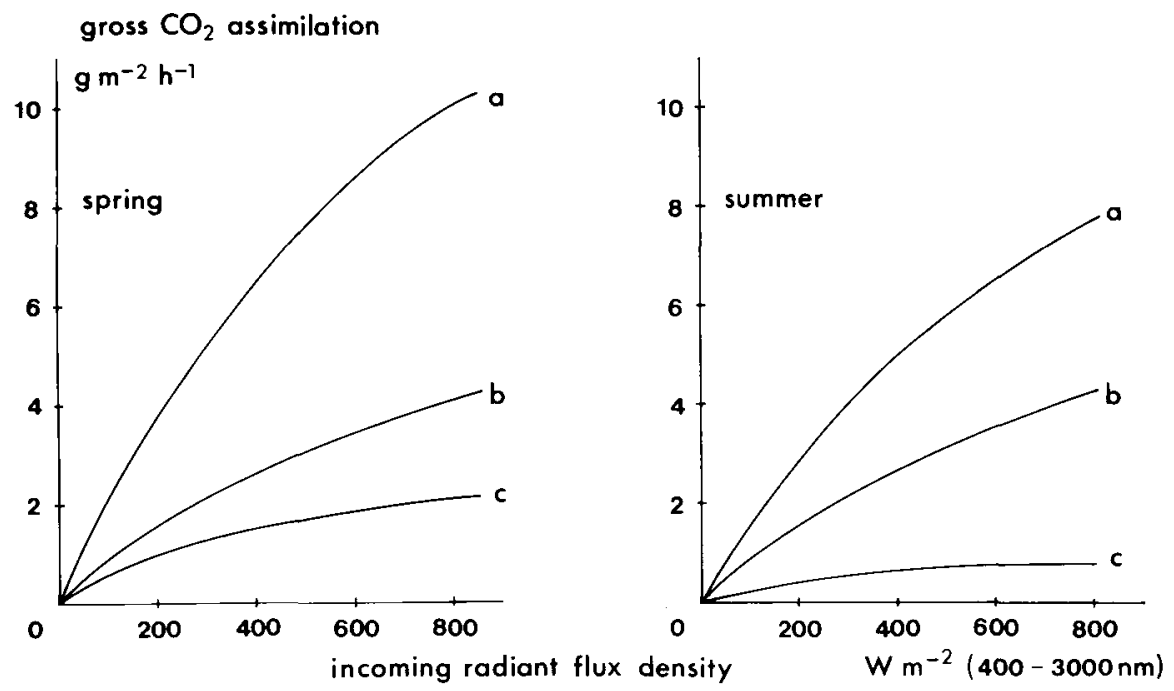

Fig. 2. Gross assimilation-light response curves measured under a clear sky at the following grazing stages: ungrazed (a), partly-grazed (b) and completely-grazed (c). Herbage mass above a 4-cm stubble: Spring: $\quad a=3105 ; b=1035 ; \mathrm{c}=0 \mathrm{~kg} \mathrm{DM} \mathrm{ha}^{-1}$ Summer: $a=2490 ; b=1245 ; c=0 \mathrm{~kg} \mathrm{DM} \mathrm{ha}^{-1}$.

The assimilation-light response curves which were used in the simulation model are shown in Fig. 2 . The curves concern ungrazed, partly grazed and completely grazed herbage. These grazing stages refer to the fractions of the initial herbage mass above a $4-\mathrm{cm}$ stubble removed by grazing cattle, which are quantified in the caption to Fig. 2. For intermediate values of the herbage mass the required curves are obtained via linear interpolation. This procedure is justified by measurements (Lantinga, unpublished data). A similar approximately linear relationship between herbage mass and assimilation rate under grazing has also been reported by King et al. (1984). The reason is that with the onset of grazing the leaves with the highest assimilation potential are removed first, thus causing a greater decrease in gross assimilation than would be expected on the basis of light interception. The choice of a reference herbage height of $4 \mathrm{~cm}$ is not fortuitous; this is the average cutting height of the motor scythes often used in grassland research.

Fig. 2 shows that, especially in the spring sward, the stubble below this cutting height has some assimilatory capacity. However, this capacity does not reflect the large amount of herbage present here. In normally treated, rotationally grazed grassland, this sward layer contains about $3000 \mathrm{~kg} \mathrm{DM} \mathrm{ha}^{-1}$ (Lantinga, 1985). The amount of green leaves is very small, however, especially in autumn, and moreover, these leaves and the sheaths show little activity. For the construction of the curves in Fig. 2, only measurements collected under a clear sky with about $90 \%$ of maximum radiation were used. At lower relative radiation levels the approach of the saturation level with increasing radiant flux density is faster, owing to the higher 


\section{E. A. LANTINGA}

Table 2. Correction factor in the calculation procedure of the gross assimilation rate. The relative radiation level is the actual radiant flux density at the moment of calculation as a fraction of its maximum value at that time (as defined by de Wit et al., 1978). The tabulated values are multiplication factors of the rate of gross assimilation under a clear sky, when the radiant flux density is about $90 \%$ of its maximum value. For intermediate cases a linear interpolation is used.

\begin{tabular}{lllllll}
\hline $\begin{array}{l}\text { Relative } \\
\text { radiation } \\
\text { level }\end{array}$ & \multicolumn{6}{l}{ Radiant flux density $\left(\mathrm{W} \mathrm{m}^{-2} ; 400-3000 \mathrm{~nm}\right)$} \\
\cline { 2 - 7 } & 0 & 100 & 200 & 400 & 600 & 800 \\
0.1 & 1.00 & 1.13 & $(1.29)$ & $(1.45)$ & & \\
0.5 & 1.00 & 1.13 & 1.29 & 1.45 & & \\
0.6 & 1.00 & 1.13 & 1.27 & 1.38 & 1.38 & \\
0.7 & 1.00 & 1.13 & 1.20 & 1.24 & 1.26 & \\
0.8 & 1.00 & 1.08 & 1.08 & 1.08 & 1.08 & 1.04 \\
0.9 & 1.00 & 1.00 & 1.00 & 1.00 & 1.00 & 1.00 \\
\hline
\end{tabular}

proportion of diffuse radiation in the incoming light (Goudriaan, 1977). This effect is corrected for by the multiplication factors of Table 2, which are experimentally and theoretically justified in another publication (Lantinga, 1986). Table 2 holds for an LAI of 5. At lower values of the LAI the required multiplication factor is somewhat lower, but the differences are slight. For reasons of simplicity only one correction table is used.

\section{Respiration and growth}

Respiration includes maintenance and growth components. The losses due to maintenance respiration are set at $0.03 \mathrm{~g}$ glucose per gramme live dry biomass at $25^{\circ} \mathrm{C}$ with a $Q_{10}$ value of 2.0 (Penning de Vries \& van Laar, 1982). For the conversion of primary assimilates into structural material an average conversion factor of $0.7 \mathrm{~g}$ $\mathrm{g}^{-1}$ is used (Penning de Vries \& van Laar, 1982).

In the model it is assumed that all, and only, current assimilates are used for maintenance and growth purposes. This assumption is based on observations made by Grant et al. (1981) in grazed and cut Lolium perenne swards. They found that in swards which were grazed for 12-day periods in summer and autumn, the level of carbohydrate reserves showed a sharp decline after the end of the grazing period. In the cutting experiment it was observed that it took more than two days before the carbohydrate concentration in the tiller bases started to decline.

\section{Distribution of assimilates}

Growth is divided among two biomass fractions: harvestable crop, and stubble and roots (Fig. 1). The stubble is the shoot layer below a sward height of $4 \mathrm{~cm}$.

Very little is known at present about the influence of the gradual herbage removal by grazing cattle on the distribution of assimilates during a rotational grazing period of a few days.

St-Pierre \& Wright (1972) working with Phleum pratense, found only minor effects on assimilate distribution 24 hours after defoliation. Ryle \& Powell (1975), by contrast, found that after defoliation the proportion of labelled assimilates translo- 
cated to meristematic leaf tissue of uniculm barley increased immediately at the expense of the allocation to the roots. But since most of the meristematic leaf tissue (shoot apex plus leaf primordia and unemerged leaves) is located in the stubble, such a change in the distribution pattern has no important influence on the carbon balance according to Fig. 1. It is assumed, therefore, that in both ungrazed and grazed herbage a constant proportion of the assimilates derived from gross assimilation minus maintenance respiration of the above-ground material is incorporated into the harvestable sward layer. This proportion is set at $70 \%$ for the spring sward and at $60 \%$ for the summer sward (Lantinga, in prep.). The remainder is used below-ground and in the stubble.

\section{Death of plant tissue}

In a grass sward there are on average three to four living leaves per tiller (Alberda \& Sibma, 1968; Sheehy et al., 1979). Thus the production of a new leaf is generally balanced by the death of an old one. In addition, a small part of the tiller population dies every day. A certain part of this dead plant material accumulates in the harvestable sward layer and eventually decomposes. In the model the rate of disappearance of dead plant tissue from the harvestable sward layer, as a result of decomposition, is set at $50 \mathrm{~kg} \mathrm{DM} \mathrm{ha}^{-1} \mathrm{~d}^{-1}$ (Sheehy et al., 1979).

\section{Herbage intake}

The rate of herbage intake at any time of the grazing period is calculated using the relationship between average herbage allowance and average herbage consumption as found by Meijs (1983) for a rotational grazing period of 3 days with an additional daily intake of $1 \mathrm{~kg}$ of concentrate-supplement per cow. This relationship can be described with the formula of Zemmelink (1980):

$$
I=I_{\mathrm{m}}\left\{1-\mathrm{e}^{-\left(p \frac{A}{I_{\mathrm{m}}}\right) h}\right\}^{1 / h}
$$

in which

$I$ is the average daily herbage intake $\left(\mathrm{kg} \mathrm{DM} \mathrm{cow}^{-1} \mathrm{~d}^{-1}\right)$;

$I_{\mathrm{m}}$ is the maximum daily herbage intake $\left(\mathrm{kg} \mathrm{DM} \mathrm{cow}^{-1} \mathrm{~d}^{-1}\right)$;

$A$ is the average daily herbage allowance $\left(\mathrm{kg} \mathrm{DM} \mathrm{cow}^{-1} \mathrm{~d}^{-1}\right)$ defined as the herbage mass at the start of grazing, plus the amount of herbage accumulated during the grazing period $\left(\mathrm{kg} \mathrm{DM} \mathrm{ha}^{-1}\right)$, divided by the number of cows per hectare and by the length of the grazing period;

$p$ is the fraction of herbage allowance which can be considered consumable;

$h$ is a shape parameter.

It was found by Meijs (1981) that $p=1$ on aftermath for a cutting height of 4.5 $\mathrm{cm}$. This value is also used here in the simulation model, where the assumed cutting height is only slightly lower $(4 \mathrm{~cm})$. The maximum daily herbage intake $\left(I_{\mathrm{m}}\right)$ is set at $18 \mathrm{~kg} \mathrm{DM} \mathrm{cow}^{-1} \mathrm{~d}^{-1}$ (Y. van der Honing, personal communication). The best fit was then obtained by setting $h$ at a value of 1.23. The resulting relation is given in Fig. 3 . 


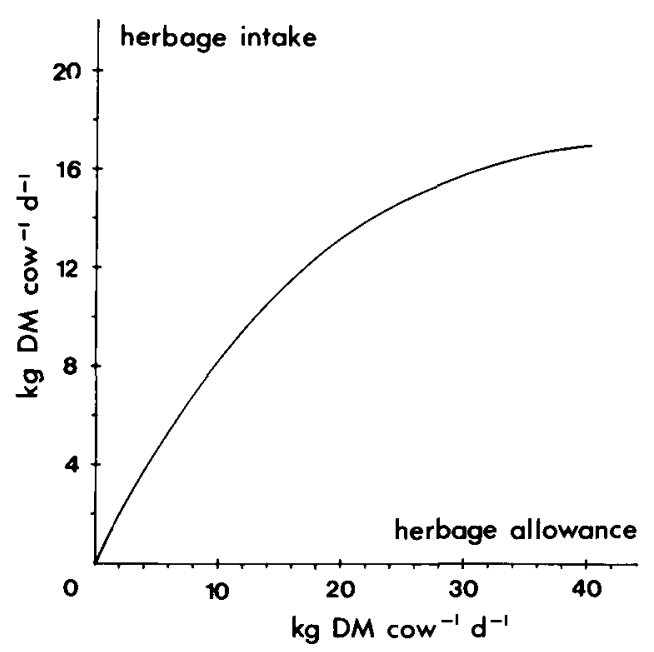

Fig. 3. Relationship between daily herbage allowance and daily herbage intake according to Eq. 4 with the parameter values given in the text.

In the model it is assumed that Eq. 4 holds throughout the grazing period. The pattern of herbage intake is then calculated as follows. At the start of the grazing period the (average) rate of herbage intake per cow is $I_{\mathrm{m}}$. This rate is realized over the chosen time interval of 1 hour. Together with the number of cows per hectare and the calculated rate of herbage production over the same time interval, this results in a new value of the herbage mass in the grazed area. All rates are then recalculated. For the calculation of the rate of herbage intake, the level of herbage allowance (A) is required. This is obtained following the definition for $\mathrm{A}$ in Eq. 4 for the duration of grazing so far. This gives a new value for the average rate of herbage intake so far. The instantaneous rate of herbage intake is calculated by comparing this value with the value one time interval earlier. This procedure is repeated until the end of the grazing cycle.

In the model it is assumed that grazing takes place 24 hours per day. This simplified approach is permissible, since it was found that the ultimate difference with more realistic grazing patterns, e.g. 8 hours per day spread over 24 hours, was very small.

\section{Harvestable herbage production}

As stated above, all, and only, current assimilates are assumed to be used for maintenance and growth. For simple simulation approaches, the rate of harvestable herbage production is then adequately defined as:

$$
\mathrm{HP}=\left(P_{\mathrm{g}}-M\right) * \mathrm{EC} * F-\mathrm{DR}
$$

where

$\mathrm{HP}$ is the rate of harvestable herbage production $\left(\mathrm{kg} \mathrm{DM} \mathrm{ha}^{-1} \mathrm{~h}^{-1}\right)$; 
$P_{\mathrm{g}} \quad$ is the rate of gross assimilation $\left(\mathrm{kg} \mathrm{CH}_{2} \mathrm{O} \mathrm{ha}^{-1} \mathrm{~h}^{-1}\right)$;

$M$ is the maintenance respiration of the above-ground material $\left(\mathrm{kg} \mathrm{CH}_{2} \mathrm{O}\right.$ ha ${ }^{-1}$ $\mathrm{h}^{-1}$;

EC is the efficiency of conversion of assimilates into structural material ( $\mathrm{kg} \mathrm{DM}$ per $\mathrm{kg} \mathrm{CH}_{2} \mathrm{O}$ );

$F \quad$ is a distribution factor for the accumulated dry matter;

DR is the decomposition rate of the harvestable shoots $\left(\mathrm{kg} \mathrm{DM} \mathrm{ha}^{-1} \mathrm{~h}^{-1}\right)$.

Eq. 5 was proposed by van Keulen (1976) as a simple method to calculate the potential crop production with time steps of one day or more. However, it can also be used in calculation procedures with shorter time steps without affecting the daily total of accumulated dry matter.

\section{Results and discussion}

Calculations were performed for a rotational grazing period of 3 days and a range of average herbage allowances between 10 and $50 \mathrm{~kg} \mathrm{DM} \mathrm{cow}^{-1} \mathrm{~d}^{-1}$. In order to compare the simulation approach with Linehan's formula the values for herbage mass used in this formula were taken from the results of the simulation.

\section{Undisturbed herbage production}

The simulated rates of undisturbed herbage production in spring and summer were approximately linearly dependent on time. This was because the assimilatory capacity of the ungrazed sward remained unchanged during the calculation periods.

In both periods it was found that the relation between the daily radiation total and the undisturbed herbage production was almost linear up to a relative radiation level of 0.5 , and levelled off between this level and 0.6 (Fig. 4). At higher relative radiation levels the rates were almost constant. This must be ascribed to the influ-

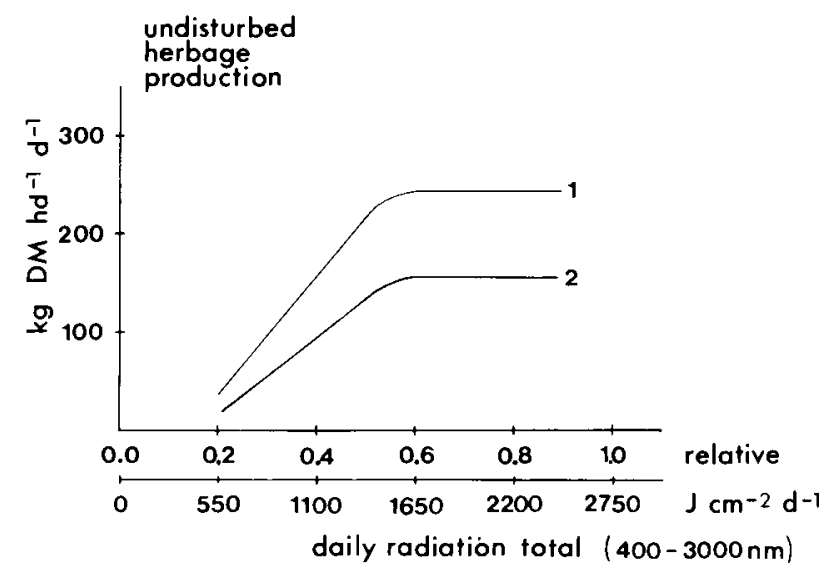

Fig. 4. Simulated rate of undisturbed herbage production in spring (1) and summer (2) as a function of the daily radiation total. 

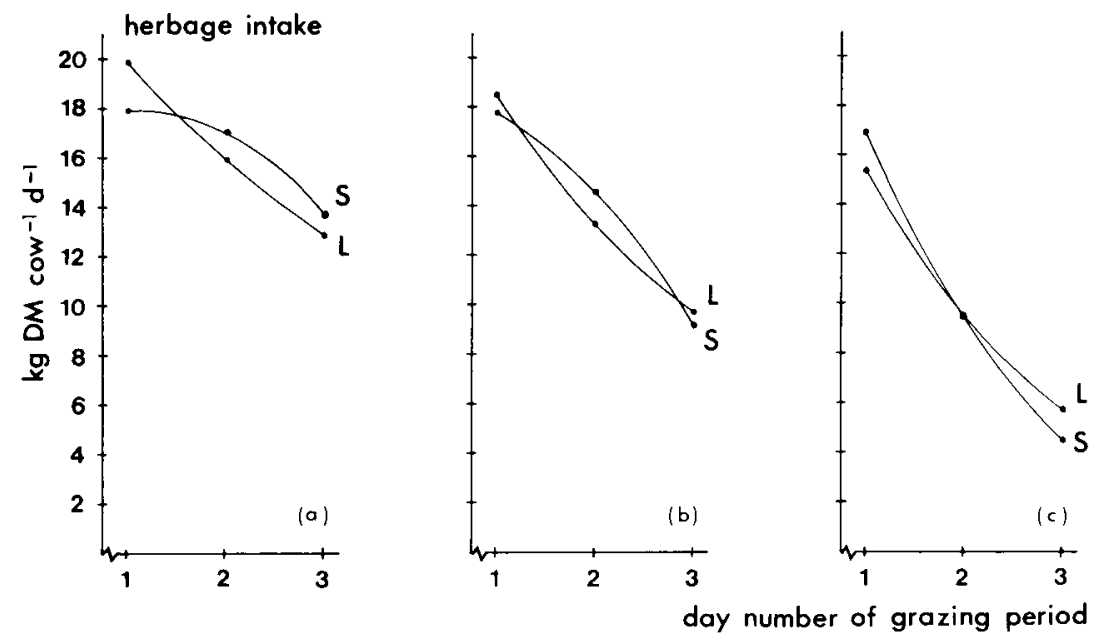

Fig. 5. Pattern of herbage intake over the grazing period according to the simulation model (S) and Linehan (L). The rate of herbage intake is given as a daily average. Herbage allowances: 33.3 (a), 22.2 (b) and 13.3 (c) $\mathrm{kg} \mathrm{DM} \mathrm{cow}^{-1} \mathrm{~d}^{-1}$.

ence of the changing composition of the incoming light on crop gross assimilation. Clearly, in the range of increasing daily radiation totals above a relative radiation level of 0.6 , the effect of the increase in the amount of direct radiation is offset by the (smaller) decrease in the amount of diffuse radiation, which is used in a much more efficient way by the sward (see Table 2).

\section{Pattern of herbage intake}

In one run of the model, in which the rate of herbage production was set at zero, the pattern of herbage intake over the grazing period was studied. This was done for three levels of average herbage allowance: $13.3,22.2$ and $33.3 \mathrm{~kg} \mathrm{DM} c \mathrm{cow}^{-1} \mathrm{~d}^{-1}$. The results are shown in Fig. 5, where the simulated pattern is compared with the negative exponential pattern according to Linehan for these average allowance levels. It can be concluded that the differences between the two intake functions are so small that only minor effects on the rate of herbage production during grazing can be expected as a result of using either one or the other function.

\section{Pattern of herbage production under grazing}

In Fig. 6 the simulated relative herbage production rates under grazing are shown together with Linehan's values, as a function of the relative herbage mass at a given moment of the grazing period for two radiation levels: $30 \%$ ('low light') and $60 \%$ ('high light') of maximum radiation. The relative herbage production rate under grazing is here the ratio between the rates of herbage production in grazed and ungrazed swards on the same day. The relative herbage mass in Fig. 6 is defined as the actual herbage mass as a fraction of the herbage mass at the end of the grazing peri- 

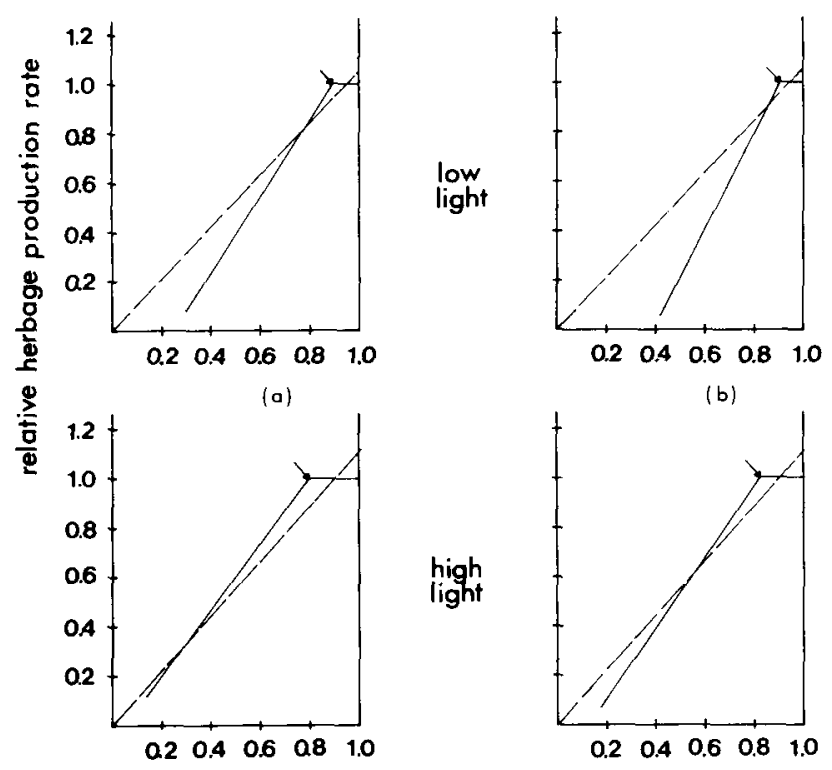

(b)

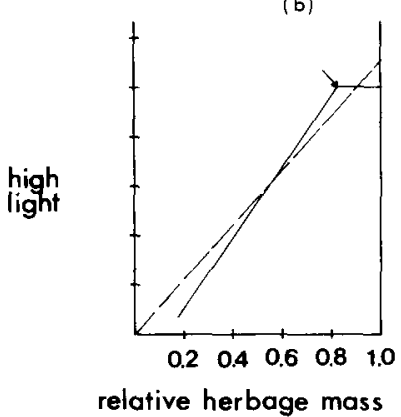

Fig. 6. Relationship between the relative herbage mass and the relative herbage production rate during grazing in spring (a) and summer (b) at low light (30\% of maximum radiation) and high light (60\% of maximum radiation and more). Broken lines: relationship according to Linehan; solid lines: relationship found with the simulation model.

od in the undisturbed situation. In all cases the simulated rates of herbage production at the start of a grazing period (indicated with an arrow) were higher than assumed by Linehan. This discrepancy was caused by the difference in the assumed growth pattern of the undisturbed sward (linear vs. exponential growth). For the grazing cycles of the present study the discrepancies were only slight, but it will be clear that these increase with the difference between the herbage mass at the start of grazing $\left(Y_{\mathrm{s}}\right)$ and that at the end of grazing in an ungrazed area $\left(Y_{\mathrm{u}}\right)$.

With low light intensity it was found that, in both periods, soon after the onset of grazing the relative herbage production rate under grazing was lower than that predicted by the Linehan equation. At low relative herbage masses this ratio even became negative. This is because the assimilatory capacity of the sward was not high enough to compensate for the losses due to maintenance respiration and decomposition.

With high light intensities the agreement improved. This is an interesting finding because, especially at high light intensity, the herbage production during grazing can introduce a bias in estimating herbage intake by the sward-cutting technique.

It can be seen from Fig. 6 that at both light levels the simulated performance in spring was somewhat better than that in summer. This is caused by the higher assimilatory capacity of the stubble in spring (see Fig. 2). 

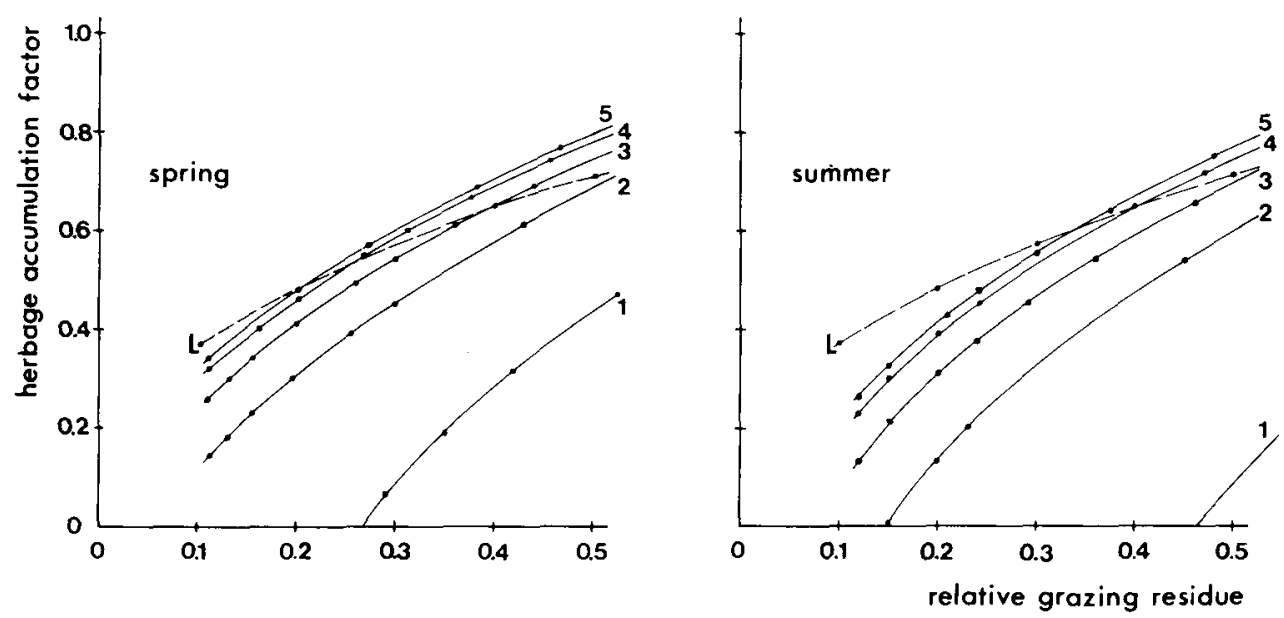

Fig. 7. Relationship between the relative grazing residue and the herbage accumulation factor as a function of the radiation level. Relative grazing residue is $Y_{\mathrm{e}} / Y_{\mathrm{u}}$ (see Eq. 1). $\mathrm{L}=$ Linehan; $1-5=$ Simulated at respectively $20,30,40,50$ and $60 \%$ and more of maximum radiation during the day.

\section{Herbage accumulation factor}

In accordance with Eq. 3 the herbage accumulation factor is defined as the total herbage production during the grazing period divided by the total herbage production in the absence of grazing. Here, the radiation level had a large effect on the simulated value of the herbage accumulation factor: the lower the radiation level during the period of grazing, the lower was the simulated herbage accumulation factor (Fig. 7). This is not surprising, as the relative carbon losses via maintenance respiration and decomposition increase more with decreasing light in a grazed than in an ungrazed sward.

In both periods it was found that at high light intensities $(\geqslant 60 \%$ of maximum radiation) the differences between the simulated value and Linehan's value of the herbage accumulation factor were slight over the range that was studied. The differences were never greater than about 0.10 units. Fig. 7 shows that, at this light level, identical results were obtained with relative herbage masses (at the end of grazing) of 0.2 in spring and of 0.35 in summer. With higher grazing residues the simulated values were slightly greater than those indicated by Linehan. Important effects on the calculated rate of herbage intake are to be expected, especially in this range, because the contribution of the herbage production during grazing to the total intake may be considerable.

\section{Total herbage consumption}

The total amount of herbage consumed is calculated as a daily average per cow over the whole grazing period. This average rate of herbage intake is of great interest in the comparison of the two calculation procedures.

It was found that at high light intensities the differences between the results of the 


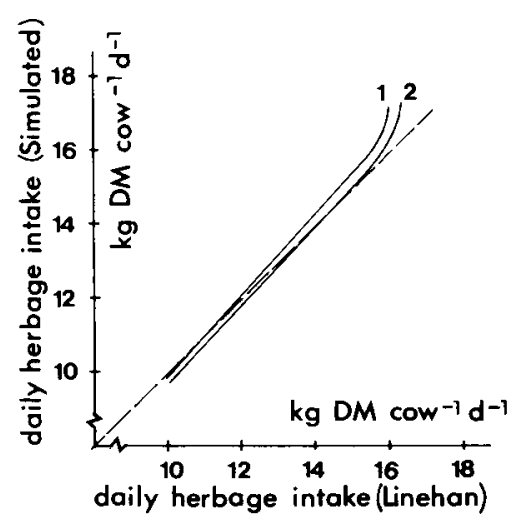

Fig. 8. Comparison of the simulated and Linehan's daily herbage intake at high light intensity. $1=$ spring; $2=$ summer.

simulation model and Linehan's formula were generally small (Fig. 8). At herbage allowance levels of practical significance, i.e. between 20 and $25 \mathrm{~kg} \mathrm{DM} \mathrm{cow}^{-1} \mathrm{~d}^{-1}$, the average level of daily herbage intake is about $14 \mathrm{~kg} \mathrm{DM} \mathrm{cow}^{-1} \mathrm{~d}^{-1}$ (Fig. 3). It can be seen in Fig. 8 that in this situation the simulation model and Linehan's formula agree very closely. According to Fig. 7, differences of any importance at this light level are to be expected only at very low and very high grazing residues. With very low grazing residues there also appeared to be a close agreement in both periods (Fig. 8). This is not surprising, because in case of a very low relative herbage mass at the end of grazing, the contribution of the accumulated herbage during the grazing period to the total amount of consumed herbage is small. For instance, the simulation showed that in both periods at an average herbage intake rate of $8 \mathrm{~kg} \mathrm{DM}$ cow $^{-1} \mathrm{~d}^{-1}$ not more than about $10 \%$ of the total intake was derived from additionally grown herbage. In such a situation, of course, a change in the value of the herbage accumulation factor has hardly any effect on the total rate of herbage intake.

Differences increase at higher herbage allowances. For instance, it was found in spring that at an average herbage allowance of $40 \mathrm{~kg} \mathrm{DM} \mathrm{cow}^{-1} \mathrm{~d}^{-1}$, the average herbage intake according to Linehan's formula was $16.2 \mathrm{~kg} \mathrm{DM} \mathrm{cow}^{-1} \mathrm{~d}^{-1}$, whereas the simulation model calculated $16.9 \mathrm{~kg} \mathrm{DM} \mathrm{cow}^{-1} \mathrm{~d}^{-1}$. However, such a level of herbage allowance is not of practical significance in intensive grassland farming.

At low light intensities the differences in herbage intake between the simulation program and Linehan's formula were never greater than a few percent (data not presented), despite the fact that in both periods the simulated value of the herbage accumulation factor was always lower than that given by Linehan (Fig. 7). But since the contribution of the herbage accumulated during the grazing period to the total intake was very small, owing to the low production rates, the calculated herbage intake was only slightly affected. 


\section{E. A. LANTINGA}

\section{Validity in other situations}

The above results show that for common rotational grazing systems, irrespective of season and radiation level, there is a close agreement between the herbage intake figures found with Linehan's formula and those yielded by a simulation approach based on measured assimilation-light response curves. A common rotational grazing system is here defined as a system with a grazing period of 3 days, a mean sward height at the start of grazing of about $18 \mathrm{~cm}$ and an average herbage allowance between 20 and $25 \mathrm{~kg} \mathrm{DM} \mathrm{cow} \mathrm{k}^{-1} \mathrm{~d}^{-1}$ measured above 4-cm stubble.

The question remains whether Linehan's formula is also of value for longer grazing periods and for other growth stages of the sward.

It was found that the larger the relative difference between the herbage mass at the start of grazing $\left(Y_{\mathrm{s}}\right)$ and the herbage mass in the absence of grazing at the end of the grazing period $\left(Y_{\mathrm{u}}\right)$, the less accurately can Linehan's formula describe the herbage production during grazing. This is because of the assumed exponential growth pattern of the ungrazed herbage, which may lead to serious underestimations of the herbage production during grazing, and therefore of the herbage intake. For this reason it is concluded that Linehan's formula may lose its validity for grazing periods longer than 3 days.

Another situation in which the difference between $Y_{s}$ and $Y_{\mathrm{u}}$ can be relatively large, even during short grazing periods, occurs when the herbage mass at the start of grazing is low. To investigate this effect of growth stage, appropriate assimilation-light response curves, derived from measurements done in other paddocks of the same experiment, were used as input in the simulation model. For this purpose grazing cycles were selected with a mean sward height at the start of grazing of about $13 \mathrm{~cm}$. It was found that in that case the value of the simulated herbage accumulation factor at all radiation levels was up to 0.20 units higher than that in the simulated curves in Fig. 7. The simulated values of the herbage accumulation factor were highest for young spring swards and for summer swards that were repeatedly grazed at a mean initial sward height of about $13 \mathrm{~cm}$. For these swards rather large differences in the calculated rates of herbage intake occurred. For instance, for a young spring sward it was found that at a herbage allowance of $29.5 \mathrm{~kg} \mathrm{DM} \mathrm{cow}^{-1}$ $\mathrm{d}^{-1}$ the herbage intake according to Linehan's formula was $13.9 \mathrm{~kg} \mathrm{DM} \mathrm{cow}^{-1} \mathrm{~d}^{-1}$, whereas the simulation model predicted $15.5 \mathrm{~kg} \mathrm{DM} \mathrm{cow}^{-1} \mathrm{~d}^{-1}$. Such discrepancies are unacceptable. A new comprehensive formula has therefore been developed to calculate the total herbage consumption correctly even in these conditions.

\section{A new formula for estimating herbage intake under rotational grazing with the sward-cutting technique}

For the derivation of this new formula, which can be seen as an improved version of Linehan's equation (Eq. 1), it is assumed that in the ungrazed situation herbage production proceeds linearly and that at the same time in the grazed situation herbage production is proportional to the amount of herbage that is present, as is illustrated in Fig. 9. The difference between these cases is that in the latter, the young 


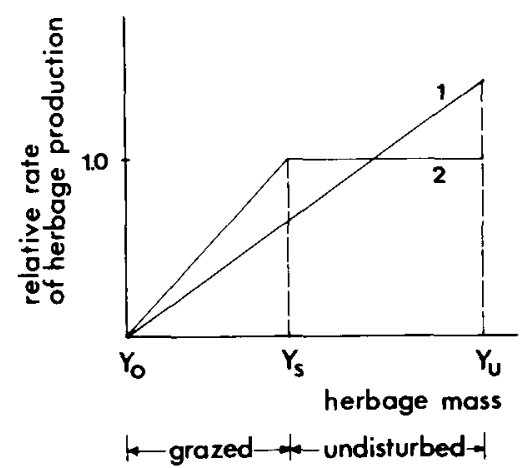

Fig. 9. Relationship of the relative rate of herbage production to the herbage mass as assumed by Linehan (1) and as used in the new approach (2). For the definitions of the herbage mass above a 4 -cm stubble see Eq. 1.

leaves with the highest potential assimilation are grazed in preference, as explained earlier. Both assumptions have been confirmed by experiment. In accordance with Linehan it is further assumed that the intake is proportional to the amount of standing herbage. The derivation proceeds now as follows.

If $k Y$ is the rate of herbage production and $h Y$ is the amount of herbage consumed per day when an amount $Y$ of herbage is available (the dimension of $k$ and $h$ is day ${ }^{-1}$ ), then the rate of net herbage production is

$$
\begin{aligned}
& \frac{\mathrm{d} Y}{\mathrm{~d} t}=(k-h) Y, \text { so } \\
& Y=Y_{\mathrm{s}} \mathrm{e}^{(k-h) t},
\end{aligned}
$$

in which $Y_{\mathrm{s}}$ is the amount of herbage at the beginning of grazing.

If $b$ is the number of grazing days, then

$$
Y_{\mathrm{e}}=Y_{\mathrm{s}} \mathrm{e}^{(k-h) b},
$$

in which $Y_{\mathrm{e}}$ is the amount of herbage at the end of the grazing period in the grazed area.

In the ungrazed area, linear growth is assumed. Consequently, the rate of undisturbed herbage production during the period of grazing is

$$
\frac{Y_{\mathrm{u}}-Y_{\mathrm{s}}}{b},
$$

in which $Y_{\mathrm{u}}$ is the yield after $b$ days in the undisturbed area.

When $t=0, Y=Y_{s}$ (Fig. 9), so at that moment the rate of herbage production is $k Y_{s}$. 


\section{E. A. LANTINGA}

Thus

$$
\mathrm{k}=\frac{Y_{\mathrm{u}}-Y_{\mathrm{s}}}{b Y_{\mathrm{s}}}
$$

Substituting (8) in (7):

$$
Y_{\mathrm{e}}=Y_{\mathrm{s}} \mathrm{e}^{\left(\frac{Y_{\mathrm{u}}-Y_{\mathrm{s}}}{b Y_{\mathrm{s}}}-h\right) b}
$$

so that

$$
h=\frac{Y_{\mathrm{u}} / Y_{\mathrm{s}}-1-\ln \left(Y_{\mathrm{e}} / Y_{\mathrm{s}}\right.}{b}
$$

The amount of herbage consumed in $b$ days is now

$$
\begin{aligned}
& h \int_{0}^{b} Y \mathrm{~d} t \\
& =\frac{Y_{\mathrm{u}} / Y_{\mathrm{s}}-1-\ln \left(Y_{\mathrm{c}} / Y_{\mathrm{s}}\right)}{b} \int_{0}^{b} Y_{\mathrm{s}} \mathrm{e}^{\left(\frac{\ln \left(Y_{\mathrm{e}} / Y_{\mathrm{s}}\right)}{b}\right) t} \mathrm{~d} t \\
& =\left(Y_{\mathrm{s}}-Y_{\mathrm{e}}\right) \frac{\left(Y_{\mathrm{u}} / Y_{\mathrm{s}}-1+\ln \left(Y_{\mathrm{s}} / Y_{\mathrm{e}}\right)\right)}{\ln \left(Y_{\mathrm{s}} / Y_{\mathrm{c}}\right)}
\end{aligned}
$$

If $Y_{\mathrm{u}}$ and $Y_{\mathrm{s}}$ differ only slightly, then Eq. 10 approaches Linehan's formula (Eq. 1), since

$$
\begin{gathered}
\operatorname{Lim}\left\{\ln \left(Y_{\mathrm{u}} / Y_{\mathrm{s}}\right)\right\}=Y_{\mathrm{u}} / Y_{\mathrm{s}}-1 . \\
Y_{\mathrm{u}} \rightarrow Y_{\mathrm{s}}
\end{gathered}
$$

This can also be seen in Fig. 9, since when $Y_{\mathrm{u}}$ equals $Y_{\mathrm{s}}$ the relationship between the relative herbage mass and the relative rate of herbage production is the same for both formulae.

Eq. 10 can also be written as

$$
\left(Y_{\mathrm{s}}-Y_{\mathrm{e}}\right)+\left\{\frac{1-\left(Y_{\mathrm{e}} / Y_{\mathrm{s}}\right)}{-\ln \left(Y_{\mathrm{c}} / Y_{\mathrm{s}}\right)}\right\}\left(Y_{\mathrm{u}}-Y_{\mathrm{s}}\right)
$$

The term between braces in Eq. 11 is the herbage accumulation factor as defined earlier (see Eq. 3).

The validity of Eq. 10 was investigated by comparing its results with the model output in the same way as has been done for Linehan's formula. This was done first 
for the two swards described in Table 1, for which Linehan's formula was satisfactory for herbage allowance levels of practical significance and for short grazing periods. Then two swards were considered for which Linehan's formula underestimated the herbage production: a young spring sward and a summer sward repeatedly grazed at a young stage. In addition, a tall spring sward with elongating stems was considered. Finally, the effect of the length of the grazing period was studied.

The results obtained at high light and a grazing period of 3 days are shown in Fig. 10. In all cases the agreement between the herbage intake calculated with Eq. 10 and that from the simulation model is excellent. In comparison with Fig. 8 it can be concluded that the deviations at high herbage allowances have disappeared. This is due to the better description of the herbage production at the beginning of the grazing period.

It may be concluded therefore that the herbage intake during short grazing periods is estimated well by Eq. 10, not only over the range of herbage allowances for which Linehan's formula is of value, but also at the high levels of herbage allowance, where Linehan's formula is less good.

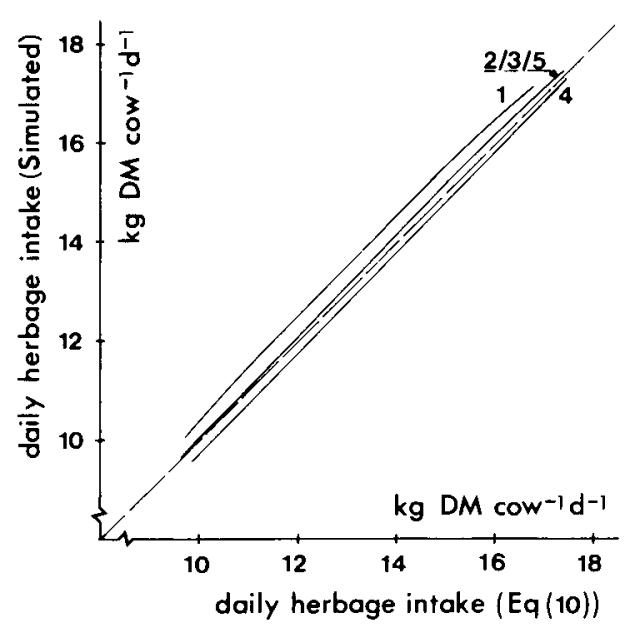

Fig. 10. Comparison of the daily herbage intake at high light calculated with the simulation program and Eq. 10.

\begin{tabular}{|c|c|c|c|}
\hline \multirow[t]{2}{*}{ Curve } & \multicolumn{3}{|c|}{ Sward conditions at the onset of grazing } \\
\hline & stage & $\begin{array}{l}\text { sward height } \\
(\mathrm{cm})\end{array}$ & $\begin{array}{l}\text { herbage mass above a } 4-\mathrm{cm} \\
\text { stubble }\left(\mathrm{kg} \mathrm{DM} \mathrm{ha} \mathrm{h}^{-1}\right)\end{array}$ \\
\hline 1 & Spring & 13.7 & $\left.2000^{*}\right)$ \\
\hline 2 & Spring & 17.1 & 3105 \\
\hline 3 & Spring & 23.5 & 3522 \\
\hline 4 & Summer & 19.1 & 2490 \\
\hline 5 & Summer & 12.1 & 1160 \\
\hline
\end{tabular}

* Estimated value. 


\section{E. A. LANTINGA}

Table 3. Influence of the length of the grazing period on the rate of herbage intake calculated with the simulation model, Eq. 10 and Linehan's formula. Conditions: spring sward (see Table 1); high light intensity; herbage allowance $=32.5 \mathrm{~kg} \mathrm{DM} \operatorname{cow}^{-1} \mathrm{~d}^{-1}$.

\begin{tabular}{llll}
\hline $\begin{array}{l}\text { Length of the grazing } \\
\text { period (days) }\end{array}$ & \multicolumn{3}{l}{ Herbage intake $\left(\mathrm{kg} \mathrm{DM} \mathrm{cow}^{-1} \mathrm{~d}^{-1}\right)$} \\
\cline { 2 - 4 } & simulation model & Eq. 10 & Linehan \\
3 & 16.1 & 16.1 & 15.5 \\
7 & 16.1 & 16.0 & 13.9 \\
\hline
\end{tabular}

The validity of Eq. 10 is compared with that of the formula of Linehan, for grazing periods longer than 3 days, in Table 3 . The results presented were obtained with the spring sward (see Table 1) at high light intensity. For the comparison, grazing periods were considered of 3 and 7 days, respectively. In both cases the average level of herbage allowance was $32.5 \mathrm{~kg} \mathrm{DM} \operatorname{cow}^{-1} \mathrm{~d}^{-1}$.

As was to be expected, Linehan's formula led to a markedly lower value of the herbage intake for the 7-day grazing period than was found with the simulation model. The new equation, however, yielded herbage intake figures which were very close to the simulated values.

The same was found for the other swards of Fig. 10, and at lower light levels (data not presented). Clearly, even for long grazing periods the validity of Eq. 10 for estimation of the herbage production during grazing is very good.

We can thus conclude that Eq. 10 is to be preferred to Linehan's formula for estimation of the herbage intake under rotational grazing using the sward-cutting technique.

\section{Acknowledgements}

This research was made possible by a scholarship from the Netherlands Organization for the Advancement of Pure Research (Z.W.O.).

Thanks are due to Prof. C. T. de Wit, Prof. L. 't Mannetje and Dr J. A. C. Meijs for their valuable comments.

\section{References}

Alberda, T. \& L. Sibma, 1968. Dry matter production and light interception of crop surfaces. III. Actual herbage production in different years as compared with potential values. Journal of the British Grassland Society 23: 206-215.

Brougham, R. W., 1956. Effect of intensity of defoliation on regrowth of pasture. Australian Journal of Agricultural Research 7: 377-387.

Goudriaan, J., 1977. Crop micrometeorology: a simulation study. Simulation Monographs Series. Pudoc, Wageningen, $249 \mathrm{pp}$.

Goudriaan, J. \& H. H. van Laar, 1978. Calculation of daily totals of the gross $\mathrm{CO}_{2}$ assimilation of leaf canopies. Netherlands Journal of Agricultural Science 26: 373-382.

Grant, S. A., G. T. Barthram \& L. Torvell, 1981. Components of regrowth in grazed and cut Lolium perenne swards. Grass and Forage Science 36: 155-168. 
Iwasaki, M., 1972. Comparison of some simplified methods for measuring the forage consumed by grazing animals. Bulletin National Grassland Research Institute 1: 31-37.

Keulen, H. van, 1976. A calculation method for potential rice production. Contributions of the Central Research Institute for Agriculture, Bogor, Indonesia, No 21, $26 \mathrm{pp}$.

King, J., E. M. Sim \& S. A. Grant, 1984. Photosynthetic rate and carbon balance of grazed ryegrass pastures. Grass and Forage Science 39: 81-92.

Lantinga, E. A., 1985. $\mathrm{CO}_{2}$ assimilation, herbage production and animal production under continuous and rotational grazing at two nitrogen levels. Mededeling No 86, Vakgroep Landbouwplantenteelt en Graslandkunde, Landbouwhogeschool, Wageningen, 43 pp.

Lantinga, E. A., 1986. Influence of the proportion of diffuse radiation on gross assimilation of leaf canopies. Submitted to Plant, Cell and Environment.

Linehan, P. A., J. Lowe \& R. H. Stewart, 1947. The output of pasture and its measurement. Part II. Journal of the British Grassland Society 2: 145-168.

Meijs, J. A. C., 1981. Herbage intake by grazing dairy cows. Agricultural Research Reports 909 . Pudoc, Wageningen, $264 \mathrm{pp}$.

Meijs, J. A. C., 1983. The influence of concentrate supplementation on herbage intake by grazing dairy cows. 2. Report of the experiment on herbage intake in 1982. Rapport I.V.V.O., Lelystad, No 149.

Penning de Vries, F. W. T. \& H. H. van Laar, 1982. Simulation of growth processes and the model BACROS. In: F. W. T. Penning de Vries \& H. H. van Laar (Eds.), Simulation of plant growth and crop production, pp. 114-135. Simulation Monographs Series. Pudoc, Wageningen, 308 pp.

Ryle, G. J. A. \& C. E. Powell, 1975. Defoliation and regrowth in the graminaceous plant: the role of current assimilate. Annals of Botany 39: 297-310.

Sheehy, J. E., J. M. Cobby \& G. J. A. Ryle, 1979. The growth of perennial ryegrass: a model. Annals of Botany 43: 335-354.

St-Pierre, J. C. \& M. J. Wright, 1972. Distribution of ${ }^{14} \mathrm{C}$ photosynthates in thimothy during the vegetative stage of growth. Crop Science 12: 191-194.

Wit, C. T. de et al., 1978. Simulation of assimilation, respiration and transpiration of crops. Simulation Monographs Series. Pudoc, Wageningen, $148 \mathrm{pp}$.

Zemmelink, G., 1980. Effect of selective consumption on voluntary intake and digestibility of tropical forages. Agricultural Research Reports 896 . Pudoc, Wageningen, $100 \mathrm{pp}$. 